\title{
Pencegahan Fraud Dengan Pengendalian Internal dalam Perspektif Alquran
}

\author{
Eko Sudarmanto ${ }^{1)}$, Citra Kharisma Utami ${ }^{2)}$ \\ ${ }^{1}$ Fakultas Ekonomi dan Bisnis, Universitas Muhammadiyah Tangerang [UMT] Indonesia \\ ${ }^{2}$ Fakultas Ekonomi, Universitas Islam Nusantara Bandung \\ *Email korespondensi: ekosudarmanto.umt@gmail.com
}

\begin{abstract}
The losses of fraudulent practices that are still occurring have become a problem for organizations and society today. The problem discussed in this study is limited fraud prevention with internal control seen from the perspective of the Qur'an, which is a holy book and the highest source of law for Moslems. This research is important to know how the perspective of the Qur'an in seeing and providing solutions to existing problems. The aim of this multi-case qualitative research is to explore methods of prevention against fraud by applying internal controls from the perspective of the Qur'an. As a conclusion, that internal control is part of corporate governance, so that management must consider the factors of thought, emotion, age, loyalty, justice, and the socio-economic environment of employees in formulating a policy. Internal controls need to be designed to be able to anticipate and prevent fraud that involves colluding with others. Internal controls can increase the ability to detect fraud by increasing effectiveness and utilizing the latest technology. Contextually, several principles in internal control are contained in several verses in the Qur'an. And what is more important is that in offering a solution to a problem, the Qur'an always provides a perspective not only materially but also spiritually.
\end{abstract}

Keywords : fraud, internal control, Alquran

Saran sitasi: Sudarmanto, E., \& Utami, C. K. (2021). Pencegahan Fraud Dengan Pengendalian Internal dalam Perspektif Alquran. Jurnal Ilmiah Ekonomi Islam, 7(01), 195-208. doi: http://dx.doi.org/10.29040/jiei.v7i1.1593

DOI: http://dx.doi.org/10.29040/jiei.v7i1.1593

\section{PENDAHULUAN}

Kecurangan atau yang lebih dikenal dengan istilah fraud, masih menjadi isu yang fenomenal dan sangat menarik untuk dibahas dan dilakukan kajian, mengingat masih banyaknya berbagai kasus fraud yang terjadi di masyarakat. Association of Certified Fraud Examiners (ACFE) mendefinisikan fraud sebagai suatu penggunaan jabatan oleh seseorang untuk memperkaya dirinya melalui penyelahgunaan yang disengaja atau penyalahgunaan penggunaan aset atau sumber daya organisasi. Atau dengan kata lain, fraud adalah kecurangan berkenaan dengan adanya keuntungan yang diperoleh seseorang dengan menghadirkan sesuatu yang tidak sesuai dengan keadaan yang sebenarnya. Di dalamnya termasuk unsur-unsur surprise / tak terduga, tipu daya, licik, dan tidak jujur yang merugikan pihak lain (ACFE, 2008). Fraud juga dapat diartikan sebagai tindakan penipuan atau kekeliruan yang dilakukan oleh seseorang atau badan yang mengetahui bahwa kekeliruan tersebut dapat mengakibatkan kerugian kepada individu atau entitas pihak lain (Surjandari \& Martaningtyas, 2015). Fraud menciptakan kesalahan penilaian atau mempertahankan penilaian salah yang ada untuk membujuk seseorang membuat suatu kontrak. Hal tersebut dilakukan karena menyangkut memperkaya diri sendiri secara sengaja dengan cara menmgurangi value/nilai aset secara rahasia (Enofe et.al., 2013).

Fraud meliputi ketidakjujuran yang disengaja, kesalahan penyajian, manipulasi dan menampilkan fakta yang dapat merugikan orang lain dan organisasi. Fraud juga meliputi pencurian, apropriasi, upaya untuk memperoleh sesuatu secara ilegal, dan kesalahan dalam membuat laporan keuangan termasuk aset dan kewajiban organisasi (Gilbert \& Wakefield, 2018). Sehingga fraud adalah penipuan yang menyertakan elemen-elemen: (a) sebuah representasi; (b) mengenai sesuatu yang bersifat material; (c) sesuatu yang tidak benar; (d) dan secara sengaja atau secara serampangan dilakukan untuk kemudian; (e) dipercaya; (f) dan ditindaklanjuti oleh 


\section{Jurnal Ilmiah Ekonomi Islam, 7(01), 2021, 196}

korban; (g) sehingga pada akhirnya korban menanggung kerugian (Zimbelman, 2014).

Secara skematis, ACFE menggambarkan fraud dalam hubungan kerja (occupational fraud) dalam bentuk fraud tree. Pohon kecurangan ini menggambarkan cabang-cabang dari kecurangan dalam hubungan kerja, beserta ranting dan anak rantingnya. Sehingga occupational fraud tree mempunyai tiga cabang utama, yaitu corruption, asset misappropriation, dan fraudulent statements (Tuanakotta, 2010).

Salah satu penjelasan teoritis mengenai penyebab seseorang melakukan fraud, pertama kali dikembangkan oleh Donald Cressey dengan teorinya yang dikenal dengan fraud triangle. Dalam teorinya dijelaskan bahwa fraud triangle dibagi menjadi tiga bagian, yaitu pressure, opportunity, dan rationalization (Cressey, 1950). Pressure adalah penggelapan uang perusahaan oleh pelaku yang bermula dari suatu tekanan. Orang tersebut mempunyai kebutuhan keuangan yang mendesak, sehingga secara personal kebutuhan individu dianggap lebih penting dari kebutuhan organisasi. Penyebab fraud kedua yaitu opportunity, dimana kecurangan akan dilakukan jika ada kesempatan dimana seseorang harus memiliki akses terhadap aset atau memiliki wewenang untuk mengatur prosedur pengendalian yang memperkenankan dilakukannya skema kecurangan. Penyebab yang ketiga yaitu rationalization, artinya kecurangan yang dilakukan karena ada rasionalisasi yang dilakukan seseorang atau kelompok orang dengan membangun pembenaran atas kecurangan yang dilakukan. Pelaku fraud biasanya mencari alasan pembenaran bahwa yang dilakukannya bukan pencurian atau kecurangan, tetapi sesuatu yang memang merupakan haknya. Namun demikian, beberapa individu lebih rentan melakukan kecurangan dibandingkan individu yang lain. Kecenderungan untuk melakukan kecurangan tergantung pada nilai-nilai etika dan keadaan pribadi mereka (Abdullahi, 2015).

Menurut laporan Association of Certified Fraud Examiners (ACFE) tahun 2020, berdasarkan frekuensi tindakan kecurangan yang terjadi, penyalahgunaan aset (asset misappropriation) merupakan tindakan kecurangan yang memiliki frekuensi tertinggi disusul oleh korupsi (corruption) dan yang terakhir adalah kecurangan laporan keuangan (financial statement fraud). Tetapi financial statement fraud adalah jenis kecurangan yang memiliki dampak kecurangan yang paling merugikan diantara jenis kecurangan lainnya (ACFE, 2020).

Kecurangan laporan keuangan dianggap sebagai kecurangan manajemen yang mengakibatkan kekeliruan bersifat material pada laporan keuangan sehingga laporan keuangan mengandung informasi yang menyesatkan. Meningkatnya berbagai kasus skandal akuntansi di berbagai negara belahan dunia menyebabkan berbagai pihak berspekulasi bahwa manajemen telah melakukan kecurangan pada laporan keuangan (Skousen \& Wright, 2009). Kecurangan laporan keuangan selalu berhubungan dengan tata kelola perusahaan. Menurut Dechow, insiden kecurangan tertinggi terjadi pada perusahaan dengan sistem tata kelola perusahaan yang lemah. Kecenderungan melakukan tindakan kecurangan sebagian besar terjadi pada perusahaan dengan latar belakang didominasi oleh pihak dalam (insider) dan kemungkinan besar tidak memiliki komite audit (Dechow, 2012).

Upaya pencegahan terhadap tindakan fraud akan lebih efektif untuk dilakukan dibandingkan dengan melakukan upaya represif. Pencegahan perlu dilakukan untuk menghindari kerugian yang lebih besar dan rusaknya reputasi institusi maupun individu. Selain itu, kejadian kecurangan yang tidak segera ditangani dan terungkap karena lambatnya penanganan akan semakin memberi peluang pelaku untuk menutupi tindakannya dengan kecurangan yang lain. Oleh karena itu perlu adanya upaya untuk melakukan pencegahan terhadap terjadinya kecurangan yang benar dan tepat sasaran, sehingga segala bentuk dan upaya praktik kecurangan dapat diantisipasi sedini mungkin agar terhindar dari risiko kerugian (Kurniasari, 2017).

Banyak upaya untuk mencegah fraud berdasarkan teori maupun penelitian yang ada, dengan harapan praktik fraud dapat diantisipasi sedini mungkin. Salah satunya adalah mencegah kecurangan dengan menerapkan pengendalian internal (internal control). Pengendalian internal merupakan bagian dari suatu sistem yang dipakai oleh manajemen untuk mengatur dan mengarahkan setiap kegiatannya. Pelaksanaan kegiatan intern dipengaruhi oleh manusia, sehingga dalam pelaksanaannya mempunyai keterbatasan dan kelemahan, diantaranya: a) kurang matangnya suatu pertimbangan dalam pengambilan keputusan; b) kegagalan menerjemahkan perintah, sehingga pelaksanaannya tidak efektif; c) pengabaian manajemen, yaitu sikap manajemen ketidak 
peduliannya terhadap kebijakan dan prosedur; d) adanya kolusi atau persekongkolan dalam pelaksanaanya, sehingga kendali yang dilaksanakan hanya formalitas (Karyono, 2013). Dengan demikian, meskipun rancangan struktur pengendaliannya handal, bila terjadi praktik yang tidak sehat maka tidak akan dapat berfungsi efektif untuk mencegah kecurangan. Ancaman aksi fraud bersifat dinamis, dan pelaku terus-menerus menyusun cara baru untuk mendapatkan target dengan mudah, dan manajemen harus memperbarui atau merancang ulang kontrol yang sesuai untuk memitigasi aksi fraud (Robinson, 2006). Menurut The Institute of Internal Auditor, bahwa tanggung jawab untuk sistem pengendalian internal di dalam sebuah organisasi adalah menjadi tanggung jawab bersama di antara para eksekutif, dengan kepemimpinan yang biasanya diberikan oleh direktur keuangan (Draz, 2011).

Di sisi lain, Islam sebagai agama yang sempurna dan sesuai dengan fitrah manusia, tentu memiliki konsep kehidupan yang sempurna dan paripurna (lihat Alquran, surah al-Maidah ayat 3). Tidak hanya mengatur hubungan manusia dengan Tuhan-nya, melainkan juga mengatur hubungan antar manusia yang dikenal dengan muamalah. Bahkan menurut penelitian yang dilakukan oleh Jalaluddin Rahmat, Islam merupakan agama yang menekankan urusan muamalah lebih besar daripada urusan ibadah ritual. Islam ternyata banyak memperhatikan aspek kehidupan sosial daripada aspek kehidupan ritual (Rahmat, 1991).

Di kalangan para ahli ilmu pengetahuan terdapat kesepakatan, bahwa dalam struktur ilmu pengetahuan terdapat ilmu yang bersifat teoritis, dan ilmu yang bersifat praktis. Ilmu yang bersifat teoritis memiliki peran sebagai dasar atau landasan untuk melakukan praktik, dan ilmu yang bersifat praktik merupakan pengamalan dari ilmu yang bersifat teoritis. Ilmu yang bersifat teoritis disebut sebagai ilmu murni (basic science), sedangkan ilmu yang bersifat praktik disebut ilmu terapan (applied science) (Nata, 2018). Dan praktik muamalah dalam ekonomi merupakan penerapan langsung ilmu terapan dengan didasarkan pada teori ilmu murni (dasar).

Meskipun muamalah dan ekonomi terus berubah dan berkembang seiring dengan perkembangan teknologi dan kebutuhan manusia, dalam Islam tidak ada suatu perkara pun yang tidak diatur melainkan semua telah ada landasan dan batasan syariat yang mengaturnya. Termasuk dalam hal bermuamalah, khususnya dalam kegiatan ekonomi dan pencegahan tindak kejahatan dan kecurangan yang terjadi, semuanya telah diatur dalam Islam yang bersumber Alquran dan as-Sunnah. Meskipun tidak semua teks ayat-ayat Alquran menjelaskan secara langsung terhadap suatu permasalahan yang ada, akan tetapi dengan metodologi penafsiran yang benar Alquran tetap dapat dijadikan rujukan utama sebagai dasar dan referensi dalam pembahasan serta penyelesaian terhadap suatu permasalahan.

Perlu diketahui bahwa dalam kajian penelitian, tafsir merupakan salah satu wilayah penelitian dalam ilmu agama Islam (Kepmenag, 1982). Metode tafsir adalah cara-cara menafsirkan Alquran yang berupa kerangka atau kaidah yang digunakan dalam menafsirkan ayat-ayat Alquran (Anwar \& A. Muharom, 2015). Sedangkan metodologi tafsir adalah pembahasan tentang metode-metode penafsiran (Baidan, 1998).

\section{METODE PENELITIAN}

Metodologi yang digunakan dalam penelitian ini adalah melalui library research, yaitu metode penelitian yang dilakukan dengan mempelajari literatur-literatur dan tulisan-tulisan yang mempunyai kaitan erat dengan permasalahan yang diajukan dalam penelitian (Baidan, 2016), melalui pendekatan kualitatif, yaitu penelitian yang menekankan analisis proses dari proses berpikir secara deduktif dan induktif yang berkaitan dengan dinamika hubungan antar fenomena yang diamati, dan senantiasa menggunakan logika ilmiah (Kisworo \& Iwan S., 2017). Penggunakan metode kualitatif juga untuk mengeksplorasi berbagai sumber data, pengamatan, dan bukti dokumenter (Slack, Corlett \& Morris, 2015; Yin, 2014).

Sumber data penelitian ini adalah terdiri dari sumber data primer berupa ayat-ayat Alquran yang dijadikan rujukan dengan penjelasan beberapa mufasir, dan sumber data sekunder yang terdiri dari karya-karya penelitian ilmiah terdahulu yang relevan, berupa buku-buku serta karya ilmiah lainnya dari berbagai sudut pandang. Sedangkan data yang digunakan adalah berbagai data kualitatif yang terjaga kualitasnya yang berbentuk kata-kata, kalimat, gerak tubuh, ekspresi wajah, bagan, gambar dan foto (Sugiyono, 2011) yang berasal dari berbagai sumber tersebut.

Metode tafsir Alquran yang dipakai sebagai metode analisis dalam penelitian ini adalah metode 


\section{Jurnal Ilmiah Ekonomi Islam, 7(01), 2021, 198}

tafsir Al-Maudhu'i yaitu tafsir yang menjelaskan beberapa ayat Alquran yang mengenai suatu judul atau topik atau sektor-sektor tertentu (Djalal, 1991).

Selanjutnya menarik kesimpulan menurut kerangka teori yang ada, yaitu yang berkaitan dengan pembahasan mengenai pencegahan fraud dengan pengendalian internal sesuai diskursus ilmiah, dilanjutkan dengan pembahasan ayat-ayat Alquran yang memiliki keterkaitan makna dalam bahasan ini menurut beberapa mufasir.

\section{LANDASAN TEORI, HASIL DAN PEMBAHASAN}

\subsection{Landasan Teori}

The Institute of Internal Auditor (IIA) suatu organisasi auditor internal di Amerika Serikat, mendefinisikan kecurangan (fraud) adalah sekumpulan tindakan yang tidak diizinkan dan melanggar hukum yang ditandai dengan adanya unsur kecurangan yang disengaja. Artinya adalah bahwa fraud merupakan kecurangan yang mengandung makna suatu penyimpangan dan perbuatan melanggar hukum yang dilakukan dengan sengaja untuk tujuan tertentu misalnya menipu atau memberikan gambaran keliru (mislead) kepada pihak-pihak lain, yang dilakukan oleh orang-orang dari dalam maupun dari luar organisasi (Karyono, 2013).

Selanjutnya, Chartered Institute of Public Finance and Accountancy (CIPFA) menyatakan fraud sebagai kesalahan yang disengaja dan menyembunyikan fakta material, penghilangan bukti untuk melakukan kecurangan dan manipulasi yang merugikan keuangan suatu individu atau organisasi. Fraud meliputi penggelapan, pencurian, pemalsuan, penyalahgunaan, dan menghilangkan bukti dengan sengaja (CIPFA, 2013).

Secara umum dapat didefinisikan bahwa fraud adalah suatu istilah yang umum, dan mencakup segala macam cara yang dapat digunakan dengan kelihaian tertentu, yang dipilih oleh seorang individu, untuk mendapatkan keuntungan dari pihak lain dengan melakukan representasi yang salah. Tidak ada aturan yang baku dan tetap yang bisa dikeluarkan sebagai proposisi umum dalam mendefinisikan fraud, termasuk kejutan, tipu muslihat, ataupun cara-cara yang licik dan tidak wajar yang digunakan untuk melakukan penipuan. Batasan satu-satunya untuk mendefinisikan fraud adalah hal-hal yang membatasi ketidakjujuran manusia (Zimbelman, 2014).
Fraud dalam organisasi korporasi umumnya berasal dari dua arah, yaitu internal dan eksternal. Fraud internal adalah kecurangan yang berasal dari pihak dalam organisasi perusahaan itu sendiri, seperti korupsi, penyajian laporan palsu, rekayasa laporan keuangan, laporan keuangan ganda, menutupi atau menyamarkan penggelapan uang, ketidakcakapan dalam penghitungan, pencurian atau penggunaan aktiva organisasi yang tidak tepat oleh para pegawai dan manajemen untuk kepentingan pribadi atau kelompok serta penggunaan yang tidak sesuai dengan peruntukannya. Sedangkan fraud eksternal yaitu kecurangan yang berasal dari pihak luar organisasi perusahaan, seperti penyuapan, peninggian nilai faktur, adanya faktur ganda serta penipuan kualitas seperti transaksi barang yang tidak sesuai dengan penyajian yang telah disepakati (Sayyid, 2014).

Kecurangan atas laporan (fraudulent statement) yaitu kecurangan dengan menyajikan laporan keuangan lebih baik dari sebenarnya (over statement) dan lebih buruk dari yang sebenarnya (under statement) (Karyono, 2013), menyajikan aset atau pendapatan lebih tinggi dari yang sebenarnya, atau menyajikan aset dan pendapatan lebih rendah dari yang sebenarnya (Tuanakotta, 2010), tindakan yang disengaja untuk menghasilkan materi laporan keuangan yang menyesatkan untuk menipu atau menggambarkan posisi keuangan organisasi yang salah (Albashrawi, 2016), membuat organisasi terlihat lebih atau kurang menguntungkan (Apostolou, 2012). Sedangkan kecurangan penyalahgunaan aset (asset misappropriation) adalah "mengambil" secara ilegal (tidak sah atau melawan hukum) yang dilakukan oleh seseorang yang diberi wewenang untuk mengelola atau mengawasi aset tersebut (Tuanakotta, 2010). Dan korupsi (corruption) adalah perbuatan yang merugikan kepentingan umum/publik atau masyarakat luas untuk kepentingan pribadi atau kelompok tertentu. Korupsi dapat terjadi pada organisasi korporasi swasta maupun pada sektor publik pemerintahan (Karyono, 2013).

Terdapat beberapa hal yang memotivasi manajemen menyajikan laporan keuangan yang mengandung unsur kecurangan: (a) memberikan dukungan agar harga saham tetap tinggi; (b) memberikan dukungan terhadap obligasi dan saham; dan (c) memaksimalkan bonus bagi manajemen (Zimbelman, 2014).

Menurut Assosiation of Certified Fraud Examiner (ACFE) dalam manual edisi ketiga, 
aksioma fraud meliputi: 1) Tersembunyi, kecurangan ini dilakukan secara tersembunyi dan berusaha untuk menutupi perbuatannya; 2) Bukti sebalik, untuk membuktikan bahwa kecurangan yang terjadi harus diusahakan agar kecurangan tersebut tidak terjadi, demikian pula sebaliknya; 3) Jenis-jenis fraud, yang terdiri dari intern fraud dan system control fraud. Intern fraud terjadi secara alamiah yang melekat dalam setiap bentuk kegiatan. System control fraud terjadi karena lemahnya sistem pengendalian internal dan biasanya pelaku mempunyai pengetahuan tentang sistem kerja internal tersebut (Karyono, 2013).

Terdapat beberapa faktor yang menyebabkan seseorang melakukan tindakan fraud. Karena hampir setiap tindakan kriminal atau kejahatan selalu didorong atau dipicu oleh suatu kondisi dan perilaku penyebab terjadinya. Dalam pembahasan ini, peneliti membatasi hanya dengan menggunakan teori Segitiga Fraud (Fraud Triangle Theory). Menurut teori ini, bahwa perilaku fraud itu terlaksana atau dilakukan karena adanya tiga unsur, yaitu adanya tekanan (pressure), kesempatan (opportunity), dan pembenaran (rationalization). Teori yang pertama kali diformulasikan oleh kriminolog Donald R. Cressey ini, menyimpulkan bahwa fraud umumnya terbagi dalam tiga ciri-ciri umum. Pertama, pelaku fraud yang memiliki kesempatan untuk melakukan penipuan (opportunity). Kedua, pelaku fraud mempunyai kebutuhan keuangan yang mendesak yang tidak dapat diceritakan kepada orang lain (pressure). Ketiga, individu yang terlibat dalam fraud merasionalisasikan perbuatan curangnya konsisten dengan kode etik pribadi mereka (rationalization) (Cressey, 1950). Dan ketiga faktor fraud tersebut diperkuat dengan hasil penelitian Skousen et. al. sebagai "triangle fraud"( Skousen et.al., 2009).

Kecurangan laporan keuangan memengaruhi berbagai pelaku pasar, termasuk investor, organisasi, dan karyawan. Sebagaimana penelitian sebelumnya memberikan informasi terkait dengan kerugian organisasi secara tidak langsung atas tindakan fraud. Selain kerugian material yang ditanggung organisasi, reputasi organisasi mungkin juga dipertanyakan ketika terjadi fraud. Kepercayaan investor pada organisasi akan hilang dan mungkin akan menarik seluruh investasinya termasuk dana pensiun (Perols, 2011).

Fraud yang terjadi pada suatu organisasi adalah sebagai manifestasi klasik dari tata kelola organisasi yang lemah. Pada organisasi swasta dikenal adanya perbedaan kepentingan antara principal dan agent. Masalah ini muncul karena ketika pemilik (principal) memberikan wewenang kepada manajer (agent) untuk bertindak atas nama mereka. Yang pada dasarnya adalah karena perbedaan kepentingan dan asimetri informasi antara manajer dan pemilik. Masalah ini dapat dihilangkan jika kedua pihak memiliki kepentingan yang sam (Jensen \& William, 1976). Dan peluang untuk melakukan fraud adalah suatu risiko yang muncul ketika pengendalian internal lemah, karena risiko untuk tertangkapnya relatif rendah (Zakaria, et.al., 2016).

Sedangakan pengendalian internal (internal control) didefinisikan sebagai rencana, metode, prosedur, dan kebijakan yang didesain oleh manajemen untuk memberi jaminan yang memadai atas tercapainya efisiensi dan efektivitas operasional, kehandalan pe;aporan keuangan, pengamanan terhadap aset, kepatuhan terhadap undang-undang, kebijakan dan peraturan lain (Kumaat, 2011). Penelitian yang dilakukan oleh Oguda Ndege et.al. (2015), juga Riri Zelmiyanti dan Lili Anita (2015), yang menyebutkan bahwa internal control sebagai proses yang dijalankan oleh dewan direksi entitas, manajemen, dan anggota lain, dirancang untuk menyediakan keyakinan yang memadai mengenai pencapaian tujuan dalam kategori efektivitas dan efisiensi operasi, keandalan dalam pelaporan keuangan, dan kepatuhan akan hukum yang berlaku dan regulasi. Sehingga dari kedua penelitian tersebut menyimpulkan bahwa internal control memiliki pengaruh yang signifikan positif untuk pencegahan fraud. Hal ini diperkuat oleh penelitian Susanto Salim (2019) yang menyimpulkan bahwa internal control merupakan cara yang paling efektif dalam perusahaan untuk meminimalisir bahkan mengeliminasi kesempatan para anggota perusahaan untuk melakukan fraud.

Dan juga memiliki peranan penting adalah audit internal harus memiliki jumlah dan kualitas sumber daya manusia yang cukup dan memiliki kompetensi yang memadai. Karena, dengan menjunjung tinggi sikap profesionalisme maka auditor akan lebih mudah dalam mendeteksi apabila terjadi kecurangan (Hutabarat, 2015). Karena berdasarkan penelitian sebelumnya ditegaskan bahwa terjadi peningkatan angka kejahatan keuangan akibat manipulasi dalam akuntansi dan kegagalan audit sehingga memiliki dampak negatif yang serius dalam ekonomi yang mengakibatkan menurunnya tingkat kepercayaan 
terhadap profesi audit (Popoola \& Samsudin, 2015). Hal ini selaras dengan temuan penelitian sebelumnya bahwa sebagian besar auditor tidak dapat mendeteksi kecurangan karena mereka bukan spesialis dalam bidang fraud, mengingat terdapat perbedaan antara audit terhadap kecurangan dan audit atas laporan keuangan.

Penelitian oleh Akbari (2013) menjelaskan bahwa pengendalian internal secara positif dapat mempengaruhi risiko operasional dan menekankan pentingnya pengendalian yang baik guna memitigasi risiko. Dan penelitian oleh Rahman dan Anwar (2014) juga menegaskan kembali argumen ini bahwa pengendalian internal diidentifikasi sebagai salah satu teknik yang paling efektif untuk mencegah kecurangan.

Terdapat beberapa unsur yang mempengaruhi lingkungan pengendalian internal: (a) integritas dan etika; (b) komitmen terhadap kompetensi; (c) pimpinan yang kondusif; (d) struktur organisasi yang mendukung; (e) pendelegasian wewenang dan tanggung jawab; (f) kebijakan dan praktik pembinaan sumber daya manusia; (g) peran pengawas internal; (h) hubungan kerja dengan instansi pemerintah terkait (Karyono, 2013).

Di dalam Alquran, terdapat beberapa ayat yang berisi tentang perilaku curang. Diantaranya di dalam surah Al-Muthaffifin, ayat 1-6 yang artinya:

"Celakalah, bagi orang-orang yang curang. Yaitu orang-orang yang apabila menerima takaran dari orang lain mereka minta dicukupkan. Dan apabila mereka menakar atau menimbang untuk orang lain, mereka mengurangi. Tidakkah mereka itu mengira bahwa sesungguhnya mereka akan dibangkitkan, pada suatu hari yang besar. Yaitu pada hari ketika semua orang bangkit menghadap Tuhan seluruh alam."

Sedangkan ayat Alquran yang berisi atau perintah untuk menyadari adanya pengawasan dan pengendalian (control) baik dalam arti khusus maupun dalam arti luas. Diantaranya adalah di dalam surah AlMujadalah, ayat 7 yang artinya:

"Tidaklah kamu perhatikan, bahwa sesungguhnya Allah mengetahui apa yang ada di langit dan apa yang ada di bumi? Tiada pembicaraan rahasia antara tiga orang, melainkan Dia-lah yang keempatnya. Dan tiada pembicaraan antara tiga orang melainkan Dialah yang keempatnya. Dan tiada pembicaraan antara lima orang melainkan Dia-lah yang keenamnya. Dan tiada pula pembicaraan antara jumlah yang kurang dari itu atau lebih banyak, melainkan Dia ada bersama mereka di manapun mereka berada. Kemudian Dia akan memberitakan kepada mereka pada hari kiamat apa yang telah mereka kerjakan. Sesungguhnya Allah Maha Mengetahui segala sesuatu."

\subsection{Pembahasan}

Fraud telah menjadi salah satu hambatan yang sangat besar dalam pembangunan ekonomi dewasa ini (Azim \& Azam, 2016). Tindakan fraud tentunya bukan suatu kesalahan biasa yang risikonya rendah, akan tetapi suatu tindakan yang disengaja dimaksudkan untuk merugikan individu majikan dan organisasi. Sehingga manajemen dan pemilik harus mempertimbangkan tentang pikiran, emosi, dan loyalitas karyawan mereka, untuk sesuatu yang lebih penting yaitu tentang kelangsungan bisnisnya (Hamilton, 2016). Ada masalah yang tentunya sangat berpengaruh terhadap perkembangan bisnis yang perlu mendapat perhatian serius dari manajemen dan pemilik, yaitu menyangkut integritas dan etika karyawan sebelum mereka diterima sebagai pekerja.

Karena sebagian besar kecurangan dilakukan oleh karyawan yang memanfaatkan kelemahan pengendalian internal, maka pengendalian internal yang ketat merupakan suatu langkah pertahanan yang efektif untuk pencegahan kecurangan (Sidden \& Simmons, 2005). Peneliti lain menjelaskan bahwa salah satu penggunaan pengendalian internal adalah untuk memastikan bahwa risiko akibat praktik kecurangan dapat dijaga seminimal mungkin (Adetiloye, et.al., 2016). Penelitian lainnya juga menemukan bahwa pembentukan sistem pengendalian internal yang memadai sangat diperlukan untuk pencegahan kecurangan (Taiwo et.al., 2016).

Organisasi harus menjaga integritas bisnis mereka melalui kejujuran dengan penyajian informasi keuangan yang akurat. Etika perilaku dalam perusahaan sangat penting untuk dipantau dan mendapat perhatian (Prentice, 2012). Termasuk beberapa faktor yang dapat mempengaruhi perilaku yang tidak beretika adalah sifat terlalu percaya diri, sikap mementingkan diri sendiri, dan rasionalisasi sebuah kekeliruan.

Berkaitan dengan pentingnya seseorang menjaga integritas dirinya dimanapun berada, telah dijelaskan di dalam Alquran surah Ash-Shaf, ayat 2-3 yang artinya: 
"Wahai orang-orang yang beriman, mengapa kamu mengatakan sesuatu yang tidak kamu kerjakan. Itu sangatlah dibenci di sisi Allah jika kamu mengatakan apa-apa yang tidak kamu kerjakan."

Ayat ini menunjukkan suatu integritas yang sebenarnya. Integritas itu meliputi kepaduan dan keutuhan pribadi. Terpadu antara kata dan perbuatan sehingga menunjukkan adanya kejujuran (al-shidq) dan konsistensi (istiqamah) dalam memperjuangkan kebenaran (Quthb, 2000). Hanya orang-orang yang memiliki integritas tinggi yang akan membawa keberuntungan dalam usaha, karena mereka menjauhkan diri dari sifat munafik dan sifat tercela lainnya.

Umumnya, ketika kontrol internal lemah atau oportunistik, penipu pemula akan dapat dengan mudah menyelesaikan tindakannya secara individu atau dengan berkolusi dengan orang lain. Seringkali ketika kecurangan terjadi, pelaku akan merekrut orang lain untuk berpartisipasi dalam tindakan kejahatan mereka. Di dalam perusahaan besar atau kecil, orang yang berkuasa seperti manajer dapat membujuk karyawan dengan sedikit kewenangannya untuk berkontribusi dalam melakukan kecurangan mereka atau dengan ancaman secara individu (Albrecht et.al., 2015). Penipu akan membujuk orang lain untuk berkolusi dan membantu mereka untuk menyelesaikan tindakan kecurangan yang tidak dapat mereka selesaikan sendiri atau agar apa yang mereka lakukan tidak dapat terdeteksi. Waddell (2016) mengatakan bahwa kolusi terjadi ketika manajemen, karyawan, atau pihak ketiga bekerja sama untuk menyembunyikan kecurangan, sehingga mengalahkan sistem kontrol internal.

Diantara ayat-ayat Alquran yang memerintahkan untuk saling tolong menolong dan bantu membantu dalam kebaikan, serta larangan untuk bekerja sama dalam dosa dan permusuhan, antara lain dalam surah Al-Ma'idah (5), ayat 2 yang artinya:

“... Dan tolong menolonglah kamu dalam mengerjakan kebajikan dan takwa, dan jangan tolong menolong dalam perbuatan dosa dan permusuhan. Bertakwalah kepada Allah, sungguh Allah sangat berat siksa-Nya."

Menafsirkan ayat ini, Ibnu Katsir mengutip sebuah hadits bahwa Imam Ahmad meriwayatkan dari Anas bin Malik, dia berkata bahwa Rasulullah SAW bersabda: "Tolonglah saudaramu yang zalim, maupun dizalimi." Dikatakan, "Wahai Rasulullah, menolong orang yang dizalimi itu dapat kami pahami, namun bagaimana bisa kami menolong orang yang berbuat zalim?" Beliau bersabda, "Cegah dan laranglah dia dari berbuat zalim, begitulah menolongnya" (ArRifai, 1999). Begitu besar manfaat dari saling membantu terhadap sesama, ternyata mengajak ke dalam kebaikan dan mencegah keburukan bisa selalu dilakukan oleh siapapun, dalam kondisi apapun, dan dengan segala kemampuan dan sarana yang dimilikinya.

Manajemen risiko dan pengendalian internal memberikan kontribusi bagi penerapan good corporate governance (GCG), khususnya dalam meningkatkan keberhasilan pencapaian sasaran organisasi. Tanpa manajemen risiko, sistem pengendalian internal menjadi berkurang keefektifannya. Sementara tanpa sistem pengendalian internal, aspek pengendalian dari GCG menjadi kurang efektif (Susilo \& Victor, 2019). Shah (2016) menyarankan bahwa organisasi harus secara sistematis mengevaluasi efektivitas langkah-langkah pencegahan kecurangan, sekaligus untuk menentukan seberapa baik kontrol yang ada mampu mengatasi risiko. Safa dan Von Solms (2016) merekomendasikan bahwa berbagi pengetahuan dalam organisasi untuk meningkatkan keamanan informasi dapat mengurangi risiko insiden keamanan.

Ayat Alquran yang memiliki makna terkait tentang pentingnya pengorganisasian atau tata kelola organisasi yang baik. Dan yang tidak boleh dilupakan dalam pengorganisasian adalah harus selalu menjaga persatuan, persaudaraan, dan kebersamaan. Sebagaimana ayat Alquran surah Ali Imran (3), ayat 103 yang artinya:

"Dan berpeganglah kamu semuanya pada tali agama Allah, dan janganlah kamu bercerai berai, dan ingatlah akan nikmat Allah kepadamu ketika kamu dahulu (masa jahiliah) bermusuhmusuhan, maka Allah mempersatukan hatimu, lalu menjadilah kamu karena nikmat Allah orang-orang yang bersaudara, dan kamu telah berada di tepi jurang neraka, lalu Allah menyelamatkan kamu dari padanya. Demikian Allah menerangkan ayat-ayat-Nya kepadamu, agar kamu mendapat petunjuk."

Menjelaskan ayat ini, yang dimaksud dengan tali Allah ialah Alquran, sebagaimana dikatakan dalam sebuah hadits al-Harits al-A'war, dari Ali mengenai sifat Alquran yang diriwayatkan secara marfu', "Alquran merupakan tali Allah yang kuat dan jalan- 
Nya yang lurus" (Ar-Rifai, 1999). Ayat ini menunjukkan akan pentingnya persatuan dan persaudaraan, yang hanya akan dicapai apabila ada suatu tali pengikat atau suatu alasan yang kuat untuk menyatukan mereka. Dan tali pengikat yang paling kuat dan paling baik itu adalah tali agama Allah yang berupa Alquran.

Meskipun dalam penelitiannya terbatas untuk memahami mengapa karyawan melakukan kecurangan terhadap perusahaan tempat mereka bekerja, Benjamin dan Samson (2011) menyelidiki adanya ketidak adilan yang dirasakan serta persepsi tidak aman dalam bekerja ternyata dapat memunculkan niat untuk melakukan kecurangan. Diungkapkan pula bahwa faktor usia memiliki pengaruh signifikan terhadap niat melakukan kecurangan (Benjamin \& Samson, 2011). Oleh karena itu perusahaan harus mempertimbangkan dan memastikan mereka memitigasi risiko-risiko tersebut agar lebih memadai. Karena kecurangan oleh karyawan tidak hanya mempengaruhi internal organisasi, tetapi juga eksternal (Peltier-Rivest \& Lanoue, 2015). Organisasi tidak hanya akan kehilangan asetnya, tetapi juga pendapatan, serta reputasinya apabila fraud telah terjadi di dalam organisasinya.

Banyak ayat-ayat dalam Alquran yang berisi tentang pentingnya bersikap dan berlaku adil. Diantaranya adalah di dalam surah An-Nahl (16), ayat 90 yang artinya:

"Sesungguhnya Allah menyuruh kamu berlaku adil dan berbuat kebajikan, memberi bantuan kepada kerabat, dan Dia melarang perbuatan keji, kemungkaran, dan permusuhan. Dia memberi pengajaran kepadamu agar kamu dapat mengambil pelajaran."

Kandungan ayat ini berisi prinsip-prinsip universal akhlak Islam dalam perilaku sosial serta keadilan, ihsan dan menjauhi kezaliman yang berdasarkan hubungan sosial. Tanpa keadilan, manusia menjadi keji dan mungkar. Allah menyuruh hamba-hamba-Nya berlaku adil, yaitu bersikap tengah-tengah dan seimbang, serta dianjurkan berbuat ihsan (Ar-Rifai, 1999). Makna yang terkandung dalam ayat ini begitu indah dan tentunya keadilan adalah suatu kebutuhan yang asasi bagi setiap insan manusia.

Robert Moeller dalam kajiannya terhadap Commitee of Sponsoring Organizations (COSO) internal control, memberikan gambaran yang jelas mengenai hubungan yang antara corporate governance - risk management - internal control. Dalam bagian yang berjudul "Clearing up a few misconception" ditegaskan bahwa, enterprise risk management (ERM) menangani lebih jauh daripada pengendalian internal. Pengendalian internal adalah bagian terpadu dari ERM. Pengendalian internal adalah salah satu bagian penting dari manajemen risiko perusahaan (Moeller, 2014).

Beberapa peneliti menfokuskan pada tanggung jawab auditor. Kostova (2013) mengungkapkan adanya hubungan antara karakteristik kecurangan dengan prosedur audit. Kostova menggambarkan adanya tanggung jawab auditor untuk mengungkapkan kesalahan dan kecurangan. Auditor diharapkan memberikan pendapat dan kesimpulan tentang keandalan laporan keuangan (Kostova, 2013). Selanjutnya diungkapan juga adanya faktor ekonomi yang menyebabkan kecurangan, serta mengidentifikasi karakteristiknya. Disebutkan bahwa lingkungan ekonomi dapat menjadi faktor utama yang mengarah pada kecurangan. Misalnya, organisasi berada di bawah tekanan untuk mencapai target keuangan.

Berbeda dengan Kostova yang fokus pada faktor ekonomi, Love (2012) meneliti tanggung jawab auditor untuk mendeteksi kecurangan yang terkait dengan standar pelaporan. Perlu diketahui bahwa standar GAAS (Generally Accepted Auditing Standards) mengakui tidak adanya kepastian untuk memberikan jaminan yang absolut, melainkan sebatas memberikan jaminan yang wajar dan mengurangi risiko material salah saji. Penemuan auditor atas informasi yang diterima memerlukan evaluasi ulang dari semua bidang audit. Karena pelaku kecurangan dapat menyembunyikan perbuatannya melalui pernyataan dan dokumen palsu selama proses audit. Love mencatat perbedaan antara melakukan audit GAAS dan pemeriksaan kecurangan. Audit GAAS akan menghasilkan opini auditor atas kewajaran presentasi laporan keuangan dan dirancang untuk mengurangi risiko salah saji secara material, sedangkan pemeriksaan kecurangan adalah aktivitas yang berbiaya tinggi karena membutuhkan pemeriksaan semua saldo material (Love, 2012).

Nicolaescu (2013) dalam penelitiannya berfokus pada peran internal audit dalam mendeteksi kecurangan. Ukuran perusahaan audit mempengaruhi kualitas terhadap laporan audit. Peneliti menemukan bahwa ketelitian dapat meningkatkan kemampuan untuk mendeteksi kecurangan. Kemampuan untuk 


\section{Jurnal Ilmiah Ekonomi Islam, 7(01), 2021, 203}

mendeteksi kecurangan juga dapat ditingkatkan dengan keberadaan auditor internal. Suatu temuan menyarankan bahwa brainstorming dapat dijadikan sarana untuk auditor internal dalam menanggapi penilaian risiko. Penelitian ini juga menyimpulkan bahwa internal audit adalah bagian yang penting dari tata kelola perusahaan (corporate governance) (Nicolaescu, 2013). Ilustrasi mudahnya adalah, pengendalian internal merupakan bagian penting dari manajemen risiko, dan manajemen risiko menjadi bagian penting dari tata kelola perusahaan.

Berhubungan dengan tanggungjawab, setidaknya terdapat 19 ayat di dalam Alquran yang berisi tentang konsep tanggung jawab. Salah satunya adalah di dalam surah Al-Mudatsir (74), ayat 38 yang artinya:

"Tiap-tiap diri bertanggung jawab atas apa yang telah diperbuatnya."

Dijelaskan bahwa tiap-tiap diri harus bertanggung jawab atas apa yang telah dikerjakannya. Dia tergadaikan, yaitu akan diazab di dalam neraka yang disebabkan oleh amal perbuatannya sendiri (AlMahalli, 2017). Segala apa yang telah dikerjakan oleh seseorang, harus dipertanggung jawabkan tidak hanya di dunia tetapi juga akan dipertanggung jawabkan kepada Allah di akhirat kelak.

Berbeda dengan peneliti lainnya, Westhausen (2017) meneliti tentang kelemahan dalam fungsi audit internal. Dalam penelitiannya disebutkan bahwa fungsi audit internal untuk mengendalikan kecurangan, saat ini sedang mengalami perkembangan. Pertumbuhan dalam teknologi, seperti sistem digital sangat membantu dalam meningkatkan efektivitas fungsi audit internal. Temuan lainnya adalah adanya kelemahan dalam pengendalian internal, yang mengesampingkan faktor kapabilitas (Westhausen, 2017). Untuk mengatasi kelemahan dari hasil temuan ini, maka sangat diperlukan adanya peningkatan pelatihan dan pengetahuan bagi pengendali internal secara terus menerus dan berkesinambungan.

Cone et.al. (2007) merekomendasikan bahwa pendidikan dan pelatihan harus diberikan dan disesuaikan guna memenuhi dan menyesuaikan persyaratan organisasi. Oleh karena itu, perusahaan perlu mendefinisikan materi pelatihan untuk memastikan bahwa materi pelatihan tersebut telah sesuai dan mencakup semua yang diperlukan guna meningkatkan kesadaran atas praktik kecurangan, termasuk membuat langkah-langkah pencegahannya yang dapat diambil (Cone, et.al., 2007).
Sebelumnya, Kranacher dan Stern memberikan saran untuk meningkatkan deteksi terhadap fraud. Menurut sebuah studi COSO (Committee of Sponsoring Organization), bahwa CEO melakukan $75 \%$ dari semua kecurangan (fraud). Sementara Klarskov Jeppesen dan Leder (2016) menyatakan perlunya auditor untuk mempertanyakan integritas manajer. Kranacher dan Stern (2004) mencatat adanya potensi konflik kepentingan antara auditor dengan pelaksana departemen perekrutan. Legislasi berfungsi sebagai pencegah bagi perilaku kecurangan, karena auditor harus secara aktif untuk mendeteksi kecurangan (Kranacher \& Stern, 2004). Rekomendasi dari temuan ini yaitu agar ditingkatkannya pendidikan auditor yang mencakup pemahaman perilaku, keterampilan investigasi dan analisis lebih dalam.

Peningkatan pengetahuan selalu diperintahkan di dalam Islam. Cukup banyak ayat-ayat Alquran berisi tentang keutamaan orang-orang yang memiliki kemampuan (kapabilitas) dalam ilmu pengetahuan. Di dalam surah Al-Mujadilah (58), ayat 11 yang artinya:

“...Niscaya Allah akan meninggikan orangorang yang beriman di antaramu dan orangorang yang berilmu pengetahuan beberapa derajat."

Ayat tersebut menjelaskan bahwa secara garis besar manusa dapat dibedakan ke dalam dua kelompok besar: pertama, orang yang sekedar beriman dan beramal; dan yang kedua, adalah orang yang beriman dan beramal shalih serta memiliki pengetahuan. Posisi atau derajat kelompok kedua ini lebih tinggi bukan saja karena nilai ilmu yang dimiliki, tetapi juga amal dan usahanya untuk mengajarkan ilmu yang dimiliki tersebut, baik melalui lisan, tulisan atau tindakan (LPMQ, 2018). Dari penjelasan ayat tersebut, diketahui bagaimana keutamaan orang-orang yang memiliki ilmu pengetahuan dibanding dengan mereka yang tidak atau kurang berilmu.

Selanjutnya, Simha dan Satyanarayan (2016) meneliti terhadap persepsi deteksi kecurangan dan metode pencegahan, dengan menggunakan wawancara auditor forensic kualitatif. Peneliti juga mempertimbangkan peran teknologi dalam deteksi dan pencegahan kecurangan. Disebutkan bahwa auditor forensic saat masih belum memadai dalam mendeteksi kecurangan, sehingga diperlukan suatu metode untuk menambah, dan meningkatkan penggunaan metode pencegahan yang lain. Para peneliti juga memberikan pengakuan tentang adanya 
peran lebih dari teknologi dalam fraud. Temuan lainnya adalah masalah keamanan dari para responden, dan adanya kebutuhan auditor untuk mendapatkan pelatihan dalam hal profil kriminal, teknologi, serta perilaku dalam keuangan (Simha \& Satyanarayan, 2016). Niranjanamurthy \& Chahar (2013) berpendapat bahwa perubahan teknologi dan bisnis yang konstan membutuhkan pendekatan terkoordinasi dengan memanfaatkan algoritma dan solusi berbasis teknologi. Krummeck (2000) merekomendasikan bahwa komunikasi adalah kunci untuk mengelola perubahan dan harus meliputi berbagai saluran komunikasi.

Di dalam Alquran terdapat banyak ayat yang menyebut tentang pentingnya menguasai ilmu pengetahuan, teknologi dan sains. Firman Allah dalam surah Ar-Rahman (55), ayat 33 yang artinya:

"Hai sekalian jin dan manusia, jika kamu sanggup menembus (melintasi) penjuru langit dan bumi, maka lintasilah. Kamu tidak dapat menembusnya kecuali dengan kekuatan."

Ayat ini menjelaskan anjuran Allah kepada jin dan manusia untuk menjelajahi semua tempat, baik di darat, laut, maupun angkasa. Ada satu syarat yang dikemukakan Allah bersamaan dengan anjuran ini, yaitu bahwa aktivitas tersebut hanya dapat dilaksanakan bila manusia dan jin memiliki ilmu yang dapat dipergunakan untuk mewujudkannya (LPMQ \& LIPI, 2018). Menurut para ulama, objek utama yang dituju oleh firman Allah ini adalah manusia. Karena manusia adalah subjek yang selalu menjadi pembicaraan utama dalam hampir seluruh ayat-ayat di dalam Alquran.

Dimitrijevic, Milovanovic, dan Stancic (2015) meneliti dengan menunjukkan bagaimana pengaruh preventif internal kontrol dapat meningkatkan kualitas pengendalian dan kinerja perusahaan secara keseluruhan. Disebutkan bahwa pengembangan sistem pengendalian internal memberikan penghalang protektif terhadap kecurangan. Selain itu, para peneliti juga membahas teknik pengendalian internal serta peran dan tanggung jawab manajemen dalam pengendalian internal (Dimitrijevic et.al., 2015). Yang perlu digarisbawahi adalah tentang perlunya pengendalian internal dan merancang teknik pencegahan untuk menghindari kecurangan.

Tentang keutamaan kualitas suatu karya atau pekerjaan, Allah berfirman di dalam Alquran surah Al-Mulk (67), ayat 2 yang artinya:
“...Supaya Allah menguji kamu, siapa di antara kamu yang lebih baik amalnya."

Dia (Allah) telah menjadikan kehidupan dan menetapkannya agar Dia menguji amal kalian, siapa yang lebih ikhlas karena Allah dan lebih taat kepadaNya (Zuhaili, et.al., 2008). Dari penjelasan ayat ini, ternyata kualitas suatu pekerjaan itu lebih diutamakan di sisi Allah dibanding dengan kuantitas. Dan bagaimana kualitas pekerjaan seseorang ternyata menggambarkan kesungguhannya, keikhlasannya, dan ketaatannya terhadap aturan yang ada.

Faktor lingkungan dan komunitas sosial memiliki pengaruh yang sangat penting bagi tindakan dan pencegahan kejahatan (Chua et.al., 2007). Demikian pula, Alfawaz et.al. mengidentifikasi lingkungan sosial sebagai faktor penting di antara faktor lainnya seperti teknologi dan regulasi. Pulz et.al. (2017) menemukan bahwa ada korelasi antara indeks sosial ekonomi terhadap kerugian karena kecurangan, sehingga ia merekomendasikan penggunaan indikator tersebut untuk memprediksi kecurangan (Pulz, et.al., 2017). Sebuah penelitian dari Igwe (2011) mengemukakan bahwa faktor sosial-ekonomi seperti pengangguran dan kemiskinan, keduanya merupakan faktor penyumbang tindak kecurangan (Igwe, 2011). Dari beberapa temuan tersebut, perlu untuk mempertimbangkan lingkungan sosial-ekonomi. Meskipun faktor tersebut berada di luar kendali perusahaan, pemahaman terhadap lingkungan yang baik, dapat menyesuaikan strategi pencegahan kecurangan secara lebih baik dan memadai.

Disebutkan ternyata lingkungan memiliki pengaruh yang sangat besar terhadap seseorang. Sebagaimana firman Allah dalam surah Al-Kahfi (18), ayat 82 yang artinya:

"Adapun dinding rumah itu adalah kepunyaan dua orang anak yatim di kota itu, dan di bawahnya ada harta benda simpanan bagi mereka berdua, sedang ayahnya adalah seorang yang shalih..."

Dalam menafsirkan "dan kedua orang tuanya adalah orang shalih," Ibnu Katsir menjelaskan bahwa ayat di atas menjadi dalil tentang keshalihan seseorang berpengaruh kepada anak cucunya di dunia dan akhirat berkat ketaatan dan syafaatnya kepada meraka, maka mereka terangkat derajatnya di surga agar kedua orang tuanya senang dan bahagia (Ar-Rifai, 2000).

Penelitian lainnya tentang metode otomatis mendeteksi fraud. Simeunović, Grubor, dan Ristic 
(2016) meneliti penggunaan analisis forensik digital untuk mendeteksi fraud. Kasus spesifik diperiksa dan diteliti terkait dengan kecurangan, hasilnya konsep yang diperkenalkan ini terbukti efektif untuk menyelidiki kecurangan dalam akuntansi dan mendeteksi bukti adanya kecurangan digital. Para peneliti mencatat bahwa dari keseluruhan $65 \%$ yang terdeteksi penipuan, $10 \%$ terdeteksi oleh auditor dan $23 \%$ terdeteksi oleh internal kontrol yang proaktif. Simeunović et.al. menambahkan bahwa pencegahan proaktif memerlukan kontrol yang memadai dan menciptakan budaya jujur serta integritas di tempat kerja. Di era big data, teknologi, dan kompleksitas sekarang ini, diperlukan adanya pendekatan gabungan analisis digital dan keterampilan audit untuk pencegahan fraud (Simeunović, et.al., 2016).

Tentang keutamaan integritas secara menyeluruh (komprehensif), Allah berfirman di dalam Alquran surah Al-Baqarah (2), ayat 208 yang artinya:

"Wahai orang yang beriman, masuklah kamu semua ke dalam Islam secara keseluruhan, dan janganlah kamu mengikuti langkah-langkah setan. Sesungguhnya ia musuh yang nyata bagimu."

Berkaitan dengan ayat ini, Ibnu Abbas dan para tabi' in mengatakan bahwa maksudnya ialah masuklah ke dalam Islam dan taatilah segala perintah-Nya secara optimal. Dan jauhilah apa-apa yang diinginkan setan kepadamu, karena sesungguhnya setan itu tiada lain hanya menyuruhmu kepada keburukan, kekejian, dan mengajakmu menjadi penghuni neraka (Ar-Rifai, 2000). Kata as-Silm berarti damai, orang yang beriman diminta agar memasukkan totalitas dirinya dalam wadah kedamaian. Ia damai dengan dirinya, keluarganya, seluruh manusia, binatang, tumbuhtumbuhan dan alam raya. Kata kaffah berarti secara menyeluruh, jangan mengamalkan sebagian ajarannya dan menolak atau mengabaikan sebagian yang lain. Karena setan selalu menggoda manusia, baik yang durhaka apalagi yang taat. Manusia supaya tidak mengikuti langkah setan, karena ia musuh yang nyata, yang menjerumuskan manusia dengan cara bertahap, sehingga ia tidak sadar telah terjerumus dalam kebinasaan (Shihab, 2000). Secara kontekstual, ayat ini menjelaskan bagaimana keutamaan suatu aktivitas pekerjaan yang apabila dilakukan dengan penuh ketekunan, kejujuran, dan benar (beramal dengan berdasarkan ilmu) akan mendapatkan hasil yang maksimal dan optimal.

\section{KESIMPULAN DAN REKOMENDASI}

\subsection{Kesimpulan}

Pengendalian internal adalah bagian dari tata kelola perusahaan, sehingga manajemen harus mempertimbangkan faktor pikiran, emosi, usia, loyalitas, keadilan, dan lingkungan sosial-ekonomi karyawan dalam menyusun suatu kebijakan. Meskipun faktor lingkungan sosial-ekonomi berada di luar kendali perusahaan, pemahaman terhadap lingkungan yang baik dapat membantu dalam penyusunan strategi pencegahan kecurangan dengan lebih baik dan memadai.

Pengendalian internal harus dirancang agar dapat mengantisipasi adanya kecurangan yang melibatkan orang lain berkolusi dan membantu pelaku dalam menyelesaikan kejahatannya supaya tidak terdeteksi. Sehingga peningkatan pengetahuan dan keterampilan bagi pengendali internal harus dilakukan secara terus menerus dan berkesinambungan.

Ketelitian pengendali internal dapat meningkatkan kemampuan dalam mendeteksi kecurangan. Untuk meningkatkan efektivitas fungsi pengendalian internal, dapat memanfaatkan teknologi terkini. Pengendali internal yang preventif dapat meningkatkan kualitas pengendalian dan meningkatkan kinerja perusahaan. Sistem pengendalian internal yang baik berfungsi sebagai penghalang (proteksi) terhadap kecurangan. Sedangkan pengendalian internal yang proaktif dan memadai dapat membangun budaya jujur menuju organisasi yang berintegritas.

Secara kontekstual beberapa prinsip temuan dalam pengendalian internal untuk mencegah terjadinya fraud terdapat di beberapa ayat dalam Alquran. Dimulai dari pentingnya integritas, kerja sama, tata kelola, keadilan, pertanggung jawaban, pendidikan, teknologi, kualitas kerja, lingkungan sosial, serta totalitas dalam berusaha. Dan yang paling penting dalam menawarkan solusi atas suatu masalah, Alquran tidak sekedar perspektif secara 'material' melainkan juga dalam perspektif spiritual.

\subsection{Rekomendasi}

Temuan yang menjadi rekomendasi dari penelitian ini, adalah bahwa secara umum telah terjadi ketidak adilan dalam ilmu pengetahuan dewasa ini. Terutama dalam hal sumber referensi dalam mencari solusi suatu masalah, masih sedikit ditemukan karyakarya ilmiah yang menjadikan Alquran sebagai solusi utama dalam penyelesaian suatu masalah dan menjadikan karya ilmuwan muslim sebagai sumber 
referensi utama. Padahal sangat banyak hasil karya ilmuwan muslim dan para mufasir yang karya mereka apabila dikaji dan dipelajari ternyata kandungan ilmu dan pengetahuan yang telah mereka hasilkan sangat dalam dan luas.

\section{REFERENSI}

Abdullahi, et.al. (2015). Fraud Triangle Theory and Fraud Diamond Theory, Understanding the Convergent and Divergent For Future Research. International Journal of Academic Research in Accounting, Finance and Management Science, 5 (4), 38-45.

Adetiloye, K.A., Olokoyo F.O. \& Taiwo J.N. (2016). Fraud Prevention and Internal Control in the Nigerian Banking System. International Journal of Economics and Financial Issues, 6 (3).

Akbari, P. (2013). A Study on Factors Affecting Operational Electronic Banking Risks in Iran Banking Industry (case study: Kermanshah melli bank). International Journal of Management and Business Research, 2 (2), 123-135.

Albashrawi, M. (2016). Detecting financial fraud using data mining techniques: A decade review from 2004 to 2015. Journal of Data Science, 14 (3), 553-569.

Albrecht, C. et.al. (2015). The role of power in financial statement fraud schemes. Journal of Business Ethics, 131, 803-813.

Al-Mahalli, Imam J. \& Imam J. As-Suyuti. (2017). Tafsir Jalalain. Bandung: Sinar Baru Algensindo.

Anwar, Rosihan \& Asep Muharom. (2015). Ilmu Tafsir. Bandung: Pustaka Setia.

Apostolou, B. \& Apostolou. (2012). The value of risk assessment: Evidence from recent surveys. The Forensic

Examiner. http://www.theforensicexaminer.com/ diunduh tanggal 05 Mei 2020.

Ar-Rifai, M. Nasib. (2000). Kemudahan Dari Allah Ringkasan Tafsir Ibnu Katsir. Jakarta: Gema Insani Press.

Azim, M.I. \& Azam S. (2016). Bernard Madoff's 'Ponzi Scheme': Fraudulent behavior and the role of auditors. Accountancy Business and the Public Interest, 15, 122-137.

Baidan, Nasruddin. (1998). Metodologi Penafsiran Alquran. Jakarta: Pustaka Pelajar.
Benjamin, O.A. \& Samson B.S. (2011). Effect of Perceived Inequality and Perceived Job Insecurity on Fraudulent Intent of Bank Employees in Nigeria. Europe's Journal of Psychology, 7 (1), 99-111.

Chartered Institute of Public Accountancy [CIPFA]. (2013). The Investigation of Fraud in the Public Sector (12 $2^{\text {th }}$ edition). London: CIPFA.

Chua, C.E.H., Wareham J. \& Robey D. (2007). The Role of Online Trading Communities in Managing Internet Auction Fraud. MIS Quarterly, 31 (4), 759-781.

Cone, B.D. et.al. (2007). A Video Game for Cyber Security Training and Awareness. Computers \& Security, 26 (1), 63-72.

Cressey, Donald. (1950). The criminal violation of financial trust. American Sociological Review, 15 (6), 738-743.

Dechow, et.al. (2012). Detevting Earning Management: A New Approach. Journal of Accounting Research, 50 Ed 2, 275-334.

DiGabriele, J.A. (2016). The expectation differences among stakeholders in the financial valuation fitness of auditors. Journal of Applied Accounting Research, 17 (1), 43-60.

Dimitrijevic, D., Milovanovic V. \& Syancic V. (2015). The role of a company's internal control system in fraud prevention. Financial Internet Quarterly “E-Finanse," 11 (3), 34-44.

Djalal, Abdul. (1991). Urgensi Tafsir Maudhu'i pada Masa Kini. Jakarta: Bulan Bintang.

Draz, Daniel. (2011). Fraud Prevention: Improving internal controls, Tahun 2011 dalam http://www.csoonline.com/article/2127917/fraud prevention/fraud-prevention-improving-internalcontrols.html diunduh 27 April 2020.

Enofe, et.al. (2013). The Impact of Forensic Accounting on Fraud Detection. European Journal of Busniness and Management, 5 (26), 61-72.

Gilbert, M. \& Wakefield A. (2018). Tackling fraud effectively in central government departments: A review of the legal powers, skills and regulatory environment of UK central government counter fraud teams. Journal of Financial Crime, 25 (2), 384-399.

Hamilton, E.L. (2016). Evaluating the intentionality of identified misstatements: How perspective can help auditors in distinguishing errors from fraud. Auditing Journal of Practice \& Theory, 35, 5778 . 
Hutabarat, Julia Fitri. (2015). Pengaruh Profesionalisme, Independensi, Kompetensi Dan Tanggunjawab Auditor Terhadap Kemampuan Auditor Dalam Mendeteksi Kecurangan. Jom FEKON, 2 (2), 1-14.

Igwe, C.N. (2011). Socio-Economic Developments and the Rise of 419 Advanced-fee Fraud in Nigeria. European Journal of Social Science, 20 (1), 184-193.

Jensen, Michael C. \& William H. Meckling. (1976). Theory of The Firm: Managerial Behafior, Agency Costs and Ownership Strucure. Journal of Financial Economics, vol. 3.

Karyono. (2013). Forensic Fraud. Yogyakarta: Andi. Kisworo, Marsudi W. \& Iwan Sofana. (2017). Menulis Karya Ilmiah Penelitian,Penulisan, Presentasi dan Publikasi Ilmiah. Bandung: Informatika.

Klarskov, Jeppesen K. \& Leder C. (2016). Auditors' experience with corporate psychopaths. Journal of Financial Crime, 23 (4), 870-881.

Kostova, S. (2013). Audit procedures for disclosure of errors and fraud in financial statements. Economic Themes, 51 (2), 355-375.

Kranacher, M.J. \& Stern L. (2004). Enhancing fraud detection through education. CPA Journal, 74 (11), 66-67.

Krummeck, S. (2000). The Role of Ethics in Fraud Prevention: A Practitioner's Perspective. Business Ethics: A European Review, 9 (4), 268272.

Kumaat, Valery G. (2011). Internal Audit. Jakarta: Penerbit Erlangga.

Kurniasari, Novia Tri. (2017). Strategi Pencegahan Kecurangan (Fraud) Dalam Pengelolaan Keuangan Badan Litbang dan Inovasi Kementrian Lingkungan Hidup dan Kehutanan. Bogor: Institut Pertanian Bogor.

Lajnah Pentashihan Mushaf al-Quran [LPMQ]. (2018). Tafsir Alquran Tematik (Jilid 8). Jakarta: Kamil Pustaka.

Lajnah Pentashihan Mushaf al-Quran \& Lemabaga Ilmu Pengetahuan Indonesia [LPMQ \& LIPI]. (2018). Mengenal Ayat-ayat Sains Dalam Alquran. Jakarta: Widya Cahaya.

Love, V.J. (2012). Auditors' responsibility for detecting fraud. CPA Journal, 82 (6), 32-38.

Moeller, Robert R. (2014). COSO Internal ControlUnderstanding and Implementing the New Framework. New Jersey: John Wiley \& Son.
Nata, Abuddin. (2018). Islam dan Ilmu Pengetahuan (1st ed.). Jakarta: Prenada Media Group.

Ndege, Oguda, Odhiambo \& Byaruhangga. (2015). Effect of Internal control on Fraud Detection and Prevention in District Treasuries of Kakamega County. International Journal of Business and Management Invention, 4 (1), 47-57.

Nicolaescu, E. (2013). Internal auditors' role in detecting fraud. Contemporary Readings in Law and Social Justice, 1, 106.

Niranjanamurthy, M. \& Chahar D. (2013). The Study of E-commerce Security Issues and Solutions. International Journal of Advanced Research in Computer and Communication Engineering, 2 (7).

Peltier-Rivest, D. \& Lanoue N. (2015). Cutting fraud losses in Canadian organizations. Journal of Financial Crime, 22, 295-304.

Perols, J. (2011). Financial statement fraud detection: An analysis of statistical and machine learning algorithms. Auditing: A Journal of Practice \& Theory, 30 (2), 19-50.

Popoola, Che-Ahmad \& Samsudin. (2015). Forensic accounting and fraud: capability and competence requirements in Malaysia. Journal of Modern Accounting and Auditing, $10 \quad$ No. 2, 825834.

Prentice, R.A. (2012). Good directors and bad behavior. Business Horizons, 55 (6), 535-541.

Pulz, J. et.al. (2017). Fraud Detection in Low-Voltage Electricity Consumers Using Socio-economic Indicators and Billing Profile in Smart Grids. Institution of Engineering and Technology, 1 .

Quthb, Sayyid. (2000). Tafsir Fi Zhilalil Quran. Jakarta: Gema Insani Press.

Rahman, R.A. \& Anwar I.S.K. (2014). Effectiveness of Fraud Prevention and Detection Techniques in Malaysian Islamic Banks. Procedia-Social and Behavioral Sciences, 145, 97-102.

Rahmat, Jalaluddin. (1991). Islam Alternatif, (Cet. $I V)$. Bandung: Mizan.

Robinson, P. (2006). Insider fraud is "serious threat." Financial Service Authority. http://news.bbc.co.uk/2/hi/business/4754840.stm diunduh tanggal 27 April 2020.

Safa, N.S. \& Von Solms R. (2016). An Information Security Knowledge Sharing Model in Organizations. Computers in Human Behaviour, $57,442-451$. 
Salim, Sussanto, et.al. (2019). Pengaruh Budaya Organisasi, Peran Auditor Internal, Peran Auditor Eksternal, dan Internal Control Terhadap Pencegahan Fraud di Surabaya. Universitas Taruma Nagara Jakarta: Conference on Management and Behavioral Studies, ISSN No. 2541-3406, 135-145.

Sayyid, A. (2014). Pemeriksaan Fraud Dalam Akuntansi Forensik dan Audit Investigatif. Al_Banjari, 13 (2), 137-162.

Shah, M.H., Ahmed J. \& Soomro Z.A. (2016). Investigating the Identity Theft Prevention Strategies in M-commerce. International Conference ITS. Melbourne.

Shihab, M. Quraish. (2000). Tafsir Al-Mishbah: Pesan, Kesan, dan Keserasian Alquran. Jakarta: Lentera Hati.

Sidden, K. \& Simmons D. (2005). Banking on Security. American City \& County, 120, 11-30.

Simeunovic, N., Grubor G. \& Ristic N. (2016). Forensic accounting in the fraud auditing case. European Journal of Applied Economics, 13 (2), 4.

Simha, A. \& Satyanarayan S. (2016). Straight from the horse's mouth: Auditors' on fraud detection and prevention, roles of technology, and whitecollars getting splattered with red! Journal of Accounting \& Finance (2158-3625), 16 (1), 2644.

Skousen, C.J. \& C.J. Wright. (2009). Detecting and Predicting Financial Statement Fraud: The Effectiveness of The Fraud Triangle and SAS No.99. Advances in Financial Economics, 13, 53-81.

Slack, R.E., Corlett S. \& Morris R. (2015). Exploring employee engagement with (corporate) social responsibility: A social exchange perspective on organizational participation. Journal of Business Ethics, 127, 537-548.

Surjandari, D.A. \& Martaningtyas I. (2015). An Empirical Study: The Effect of Performance Incentives, Internal Control System, Organizational Culture, or Fraud of Indonesia Government Officer. Mediteranian Journal of Social Sciences, 6 (5), 71-76.
Susilo, Leo J. \& Victor R. Kaho. (2019). Manajemen Risiko Panduan Untuk Risk Leaders dan Risk Practitioners (II). Jakarta: Grasindo.

Taiwo, J. et.al. (2016). Growth of Bank Frauds and the Impact on the Nigerian Banking Industry. Journal of Business Management and Economics, 4 (12), 1-10.

The Association of Certified Fraud Examiner [ACFE]. (2008). The Report to The Nation on Occupational Fraud and Abuse. Texas: Austin.

The Association of Certified Fraud Examiner [ACFE]. (2020). Report to Nation 2020. https://www.acfe.com/uploadedFiles/ACF diunduh tanggal 19 April 2020.

Tuanakotta, Theodorus M. (2010). Akuntansi Forensik \& Audit Investigative (2nd ed.). Jakarta: Salemba Empat.

Waddell, C. (2016). Using network analysis to detect collusive fraud: Could notorious fraudsters have been caught in the act? The CPA Journal, 86 (3), $1-8$.

Westhausen, H.U. (2017). The escalating relevance of internal auditing as anti-fraud control. Journal of Financial Crime, 24 (2), 322.

Yin, R.K. (2014). Case study research: Design and methods $\left(5^{\text {th }}\right.$ ed.). Thousand Oaks, CA: Sage Publication, inc.

Zelmiyanti, Riri \& Anita L. (2015). Pengaruh Budaya Organisasi Dan Peran Auditor Internal Terhadap Pencegahan Kecurangan Dengan Pelaksanaan Sistem Pengendalian Internal Sebagai Variabel Intervening. Jurnal Akuntansi Keuangan Dan Bisnis, 67-76.

Zimbelman, Mark F, et.al. (2014). Akuntansi Forensik. Jakarta: Salemba Empat.

Zuhaili, Wahbah, et.al. (2008). Buku Pintar AlquranSeven in One. Jakarta: Almahira. 